Article

\title{
Atractylenolide II Inhibits Proliferation, Motility and Induces Apoptosis in Human Gastric Carcinoma Cell Lines HGC-27 and AGS
}

\author{
Shuang Tian * and Hongdan Yu \\ Department of Cell Biology, Jinzhou Medical University, Jinzhou 121000, China; yuhongdan1116@126.com \\ * Correspondence: tianshuangsj@163.com; Tel.: +86-416-4673-073
}

Received: 25 October 2017; Accepted: 1 November 2017; Published: 3 November 2017

\begin{abstract}
Atractylenolide II (AT-II) exhibits several biological and pharmacological functions, especially anti-cancer activity as the major sesquiterpene lactones isolated from Atractylodes macrocephala (also named Baizhu in Chinese). However, the effects and mechanisms of AT-II on human gastric cancer remain unclear. Cell Counting Kit-8 (CCK-8) assay, morphological changes, flow cytometry, wound healing assay and Western blot analysis were used to investigate the effects of AT-II on cell proliferation, apoptosis and motility of human gastric carcinoma cell lines HGC-27 and AGS. Our results indicated that AT-II could significantly inhibit cell proliferation, motility and induce apoptosis in a dose and time-dependent manner. Western blot analysis showed that the expression level of Bax was upregulated and the expression levels of B-cell lymphoma-2 (Bcl-2), phosphorylated-protein kinase B (p-Akt) and phosphorylated-ERK (p-ERK) were downregulated compared to control group. In conclusion, the findings suggested that AT-II exerted significant anti-tumor effects on gastric carcinoma cells by modulating Akt/ERK signaling pathway, which might shed light on therapy of gastric carcinoma.
\end{abstract}

Keywords: Atractylenolide II; gastric carcinoma; proliferation; apoptosis; motility

\section{Introduction}

Gastric cancer is the fifth most common cancer and the second leading cause of cancer-related deaths in the world [1,2]. Although advanced surgeries and chemotherapy treatments are the most effective therapeutic methods for gastric cancer, there is still a high death rate and a low survival rate [3-5]. Therefore, it is urgent to find a novel agent that could improve the survival rate and alleviate the pain of gastric cancer patients.

Nowadays, more and more naturally bioactive compounds found in vegetables [6], pharmaceutical plants $[7,8]$ and fruits are given special attention by researchers because of their high activity and low cytotoxicity. Atractylodes macrocephala belongs to the composite family has been an important traditional herbal medicine in Asia, which is widely used to treat dyspepsia, diarrhea, stomach diseases, diabetes and anti-abortion [9-12]. It is also popularly used as heath cultivating food. There are a large number of natural compounds that extracted from Atractylodes macrocephala, such as polysaccharides, sesquiterpenoids and volatile oils [13]. AT-II as the major sesquiterpenoids isolated from the dried Rhizome of Atractylodes macrocephala shows a wide range of biological and pharmacological activities, for example, against insomnia and anxiety, neuroprotective, platelet activation and anti-cancer effect [14-17]. Previous studies reported that AT-II could inhibit cell proliferation, arrest G1 phase cell cycle and induce apoptosis in B16 cell [18]. However, the effects and mechanisms of AT-II on human gastric cancer remain elusive.

The purpose of our study is to investigate the effects of AT-II on cell proliferation, motility and apoptosis of gastric carcinoma cells and its possible molecular mechanisms, which would provide valid data for the application of AT-II to treat gastric carcinoma in the future. 


\section{Results}

\subsection{AT-II Inhibits Proliferation in HGC-27 and AGS Cells}

To research the effects of AT-II on cell growth, CCK-8 assays were used to determine relative cell viability. As shown in Figure 1, AT-II treatment groups showed significant inhibitory effects on HGC-27 and AGS cells compared to control group in a concentration and time-dependent manner. Moreover, HGC-27 cells are more sensitive than AGS cells to AT-II. When HGC-27 cells were exposed to $200 \mu \mathrm{M}$ of AT-II for $48 \mathrm{~h}$, the cell viability reduced to nearly $50 \%$, while AGS needed $400 \mu \mathrm{M}$ of AT-II treatment. However, even if treated with $400 \mu \mathrm{M}$ of AT-II for $48 \mathrm{~h}$, it had no cytotoxicity on human normal gastric mucosal epithelium GES-1 cells.
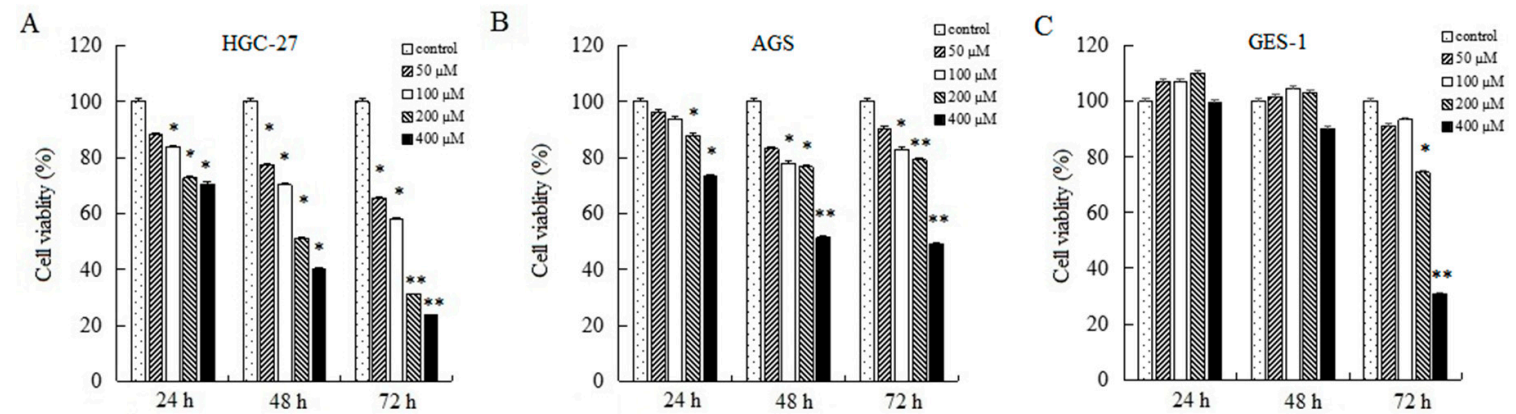

Figure 1. Inhibitory effects of AT-II on cancer cell growth. (A) HGC-27, (B) AGS and (C) GES-1 cells were treated with AT-II at different concentrations for $24 \mathrm{~h}, 48 \mathrm{~h}$ and $72 \mathrm{~h}$. Cell viability was examined by CCK-8 assay. All data were obtained from three independent experiments and expressed as mean \pm SD. ${ }^{*} p<0.05$ and ${ }^{* *} p<0.01$ vs. control group.

\subsection{AT-II Affects Morphological Changes}

After being treated with AT-II for $48 \mathrm{~h}$, the morphological changes of HGC-27 and AGS cells were observed with an inverted microscope, which had remarkable differences from the control group. Compared to control group, the majority of HGC-27 and AGS cells treated with AT-II were obviously reduced, distorted and grew slowly. In addition, with a high dose of AT-II treatment, the cell membrane became rough and emerged blebbing and swelling (Figure 2).

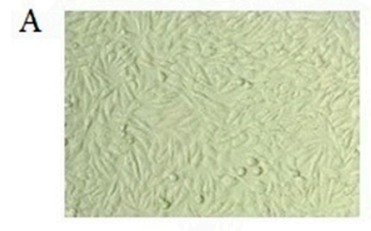

B

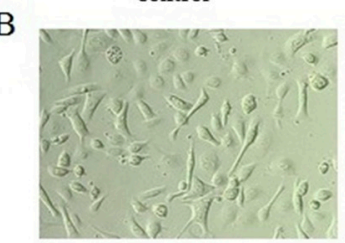

control

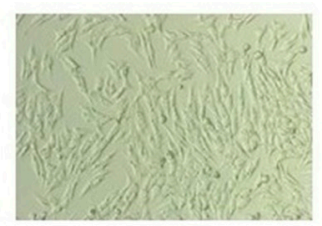

$50 \mu \mathrm{M}$

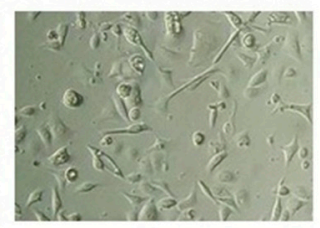

$50 \mu \mathrm{M}$

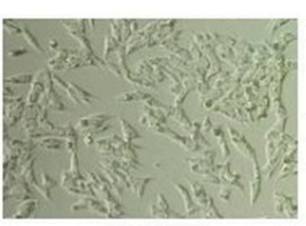

$100 \mu \mathrm{M}$

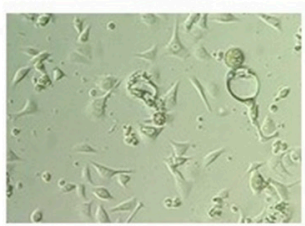

$100 \mu \mathrm{M}$

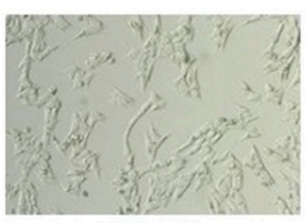

$200 \mu \mathrm{M}$

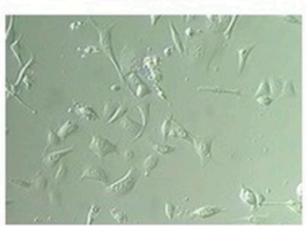

$200 \mu \mathrm{M}$

Figure 2. Morphological changes of HGC-27 and AGS cells treated with AT-II for $48 \mathrm{~h}$ and observed with an inverted microscope $\times 200$ magnification. (A) HGC-27 cells; (B) AGS cells. 


\subsection{AT-II Induces Apoptosis in HGC-27 and AGS Cells}

HGC-27 and AGS cells were treated with various doses of AT-II for $48 \mathrm{~h}$ and stained with Annexin V-FITC/Propidium Iodide (PI). Flow cytometry results demonstrated that cell apoptosis rates of HGC-27 and AGS cells were positively correlated with the concentration of AT-II. The upper right quadrant represented late apoptotic cells and the lower right quadrant represented early apoptotic cells. Treated with $50 \mu \mathrm{M}$ of AT-II, cell apoptosis rate did not have differences from control group in HGC-27 cells, but the percentages of apoptotic cells were significantly increased with the increasing AT-II concentrations (Figure 3A). However, AGS cells were less sensitive to AT-II than HGC-27 cells and when only exposed to $200 \mu \mathrm{M}$ of AT-II, AGS cells could exhibit remarkable apoptosis (Figure 3B).

A
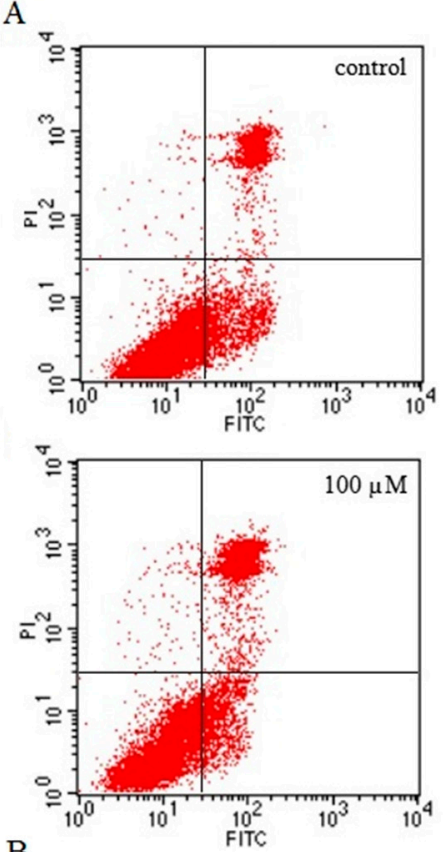

$\mathrm{B}$
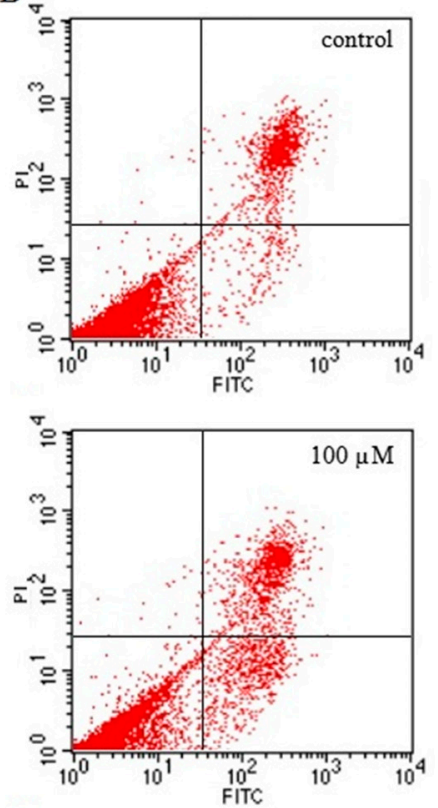
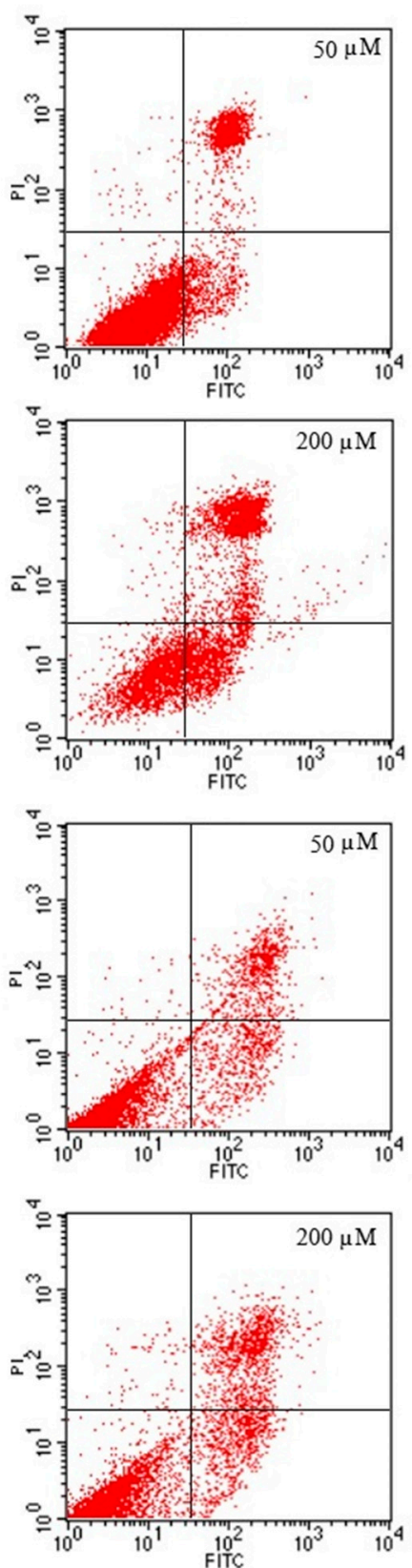

$\mathrm{C}$

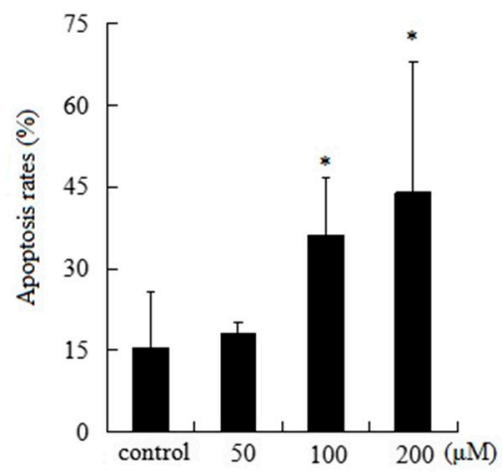

$\mathrm{D}$

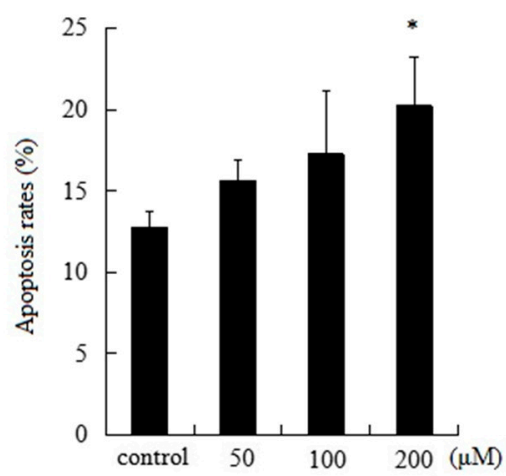

Figure 3. Apoptotic effects of AT-II on HGC-27 and AGS cells for 48 h. (A) HGC-27 cells; (B) AGS cells; (C) the percentages of apoptotic cells in HGC-27 cells; (D) the percentages of apoptotic cells in AGS cells. All experiments were performed in triplicates and expressed as mean \pm SD. ${ }^{*} p<0.05$ vs. control group. 


\subsection{AT-II Suppresses the Capability of Cell Motility}

To determine the effect of AT-II on cell migration, cells were exposed to AT-II with different concentrations for $0 \mathrm{~h}, 24 \mathrm{~h}$ and $48 \mathrm{~h}$ and wound healing assays were applied to detect the relative migration distance. The results showed a striking difference in cell mobility between control group and AT-II treatment groups. Cells in AT-II treatment groups migrated more slowly. In addition, as time and dose increased, the differences of migration rate were gradually significant between the four groups (Figure 4).

A

$\mathrm{Oh}$

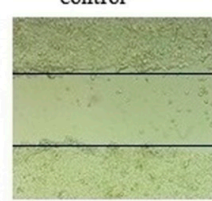

$24 \mathrm{~h}$

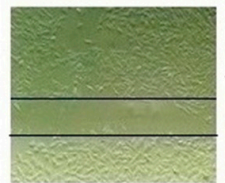

$48 \mathrm{~h}$

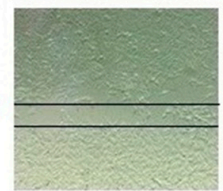

control

$\mathrm{Oh}$
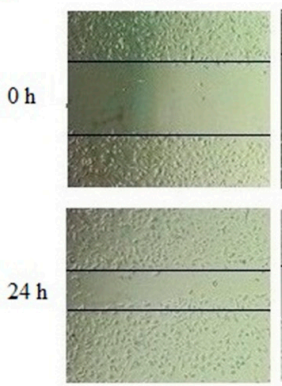

$48 \mathrm{~h}$

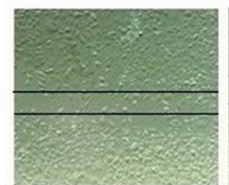

$50 \mathrm{uM}$

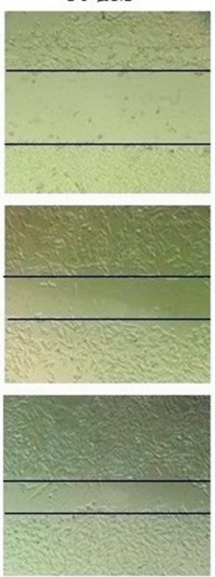

$50 u \mathrm{M}$
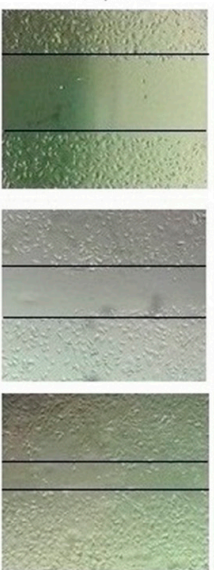

$100 \mu \mathrm{M}$
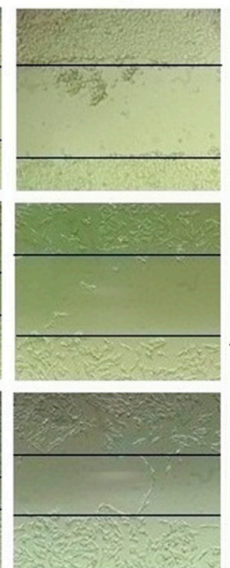

$100 \mu \mathrm{M}$
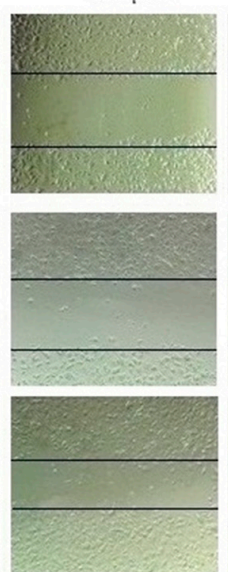

$200 \mu \mathrm{M}$

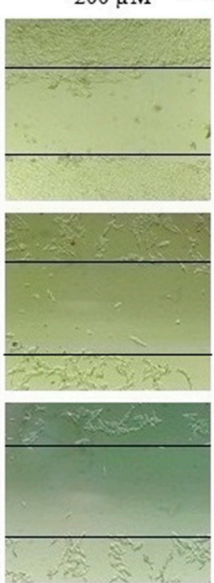

$200 \mu \mathrm{M}$
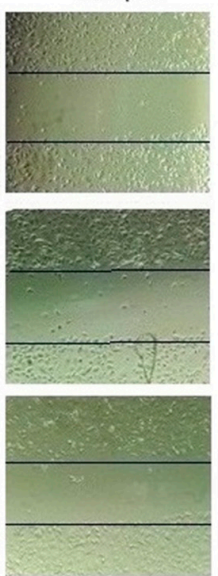

$\mathrm{C}$

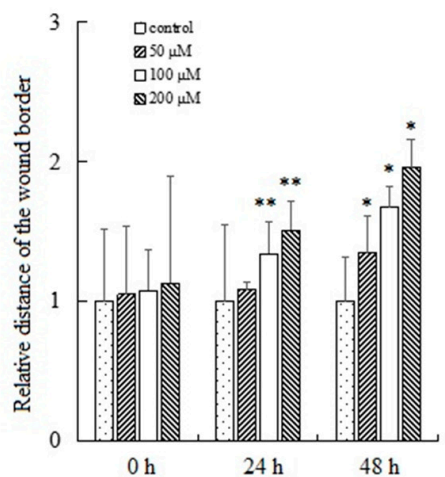

D

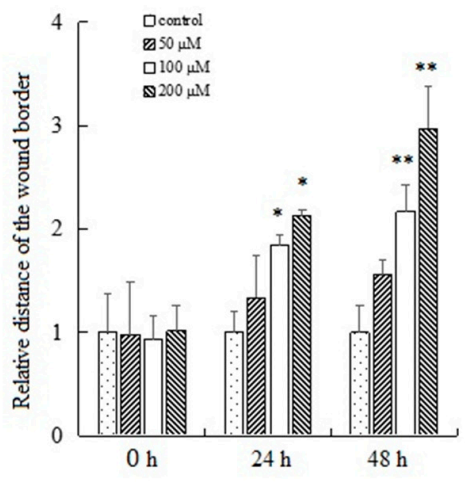

Figure 4. Examination of the motility of HGC-27 and AGS cells by wound healing assay. (A) HGC-27 cells; (B) AGS cells; (C) the relative distances of the wound border in HGC-27 cells; (D) the relative distances of the wound border in AGS cells. All experiments were performed three times and expressed as mean \pm SD. $* p<0.05$ and ${ }^{* *} p<0.01$ vs. control group.

\subsection{AT-II Regulates the Protein Expression Levels of Bax and Bcl-2}

The intrinsic apoptosis pathway is mostly regulated by Bcl-2 family proteins and the pro-apoptotic protein Bax and the anti-apoptotic protein Bcl-2 are typically involved in apoptosis and cellular proliferation [19]. Moreover, the ratio of Bax and Bcl-2 has a key role in the development of apoptosis. Our results indicated that AT-II can significantly upregulate the expression level of Bax, and significantly downregulate the expression level of Bcl-2 in a dose-dependent manner in two cell lines. In addition, as the dose of AT-II increased, the ratio of Bax/Bcl-2 also increased (Figure 5). 
A

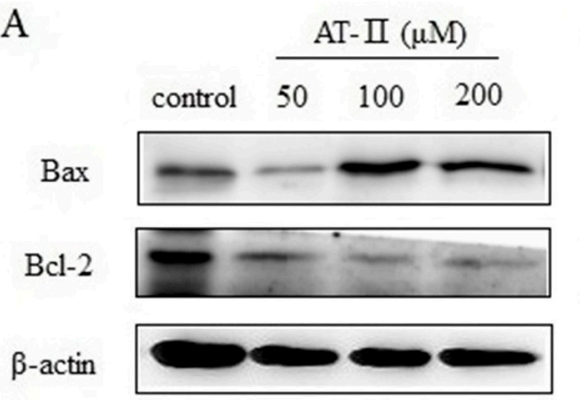

B

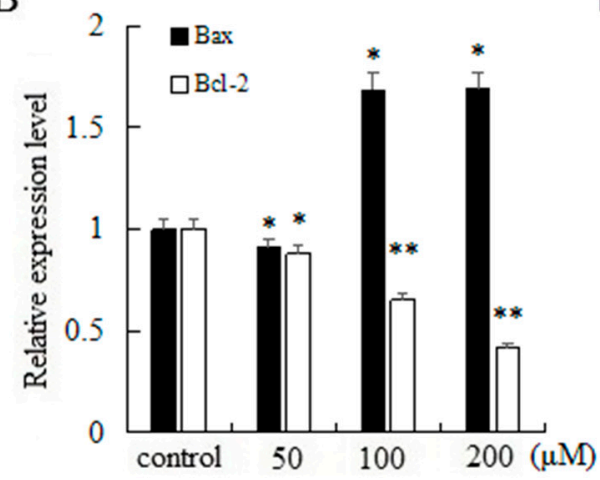

$\mathrm{D}$

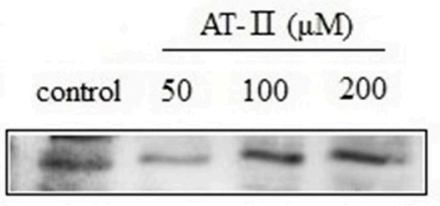

$\mathrm{Bcl}-2$

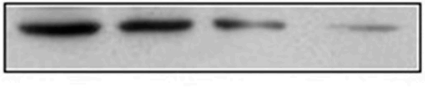

$\beta$-actin

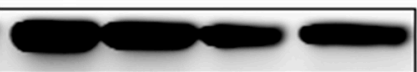

E

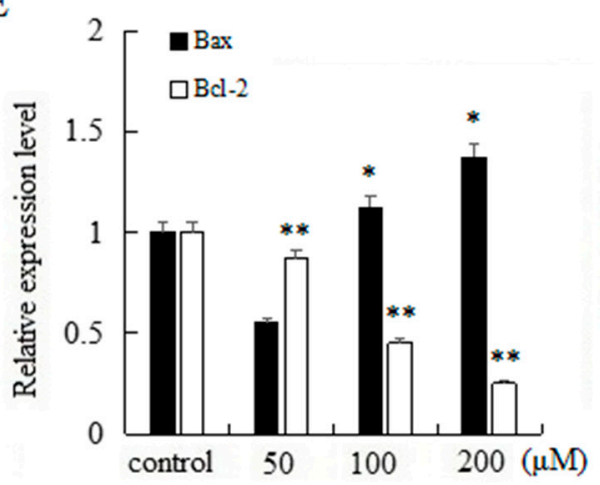

F

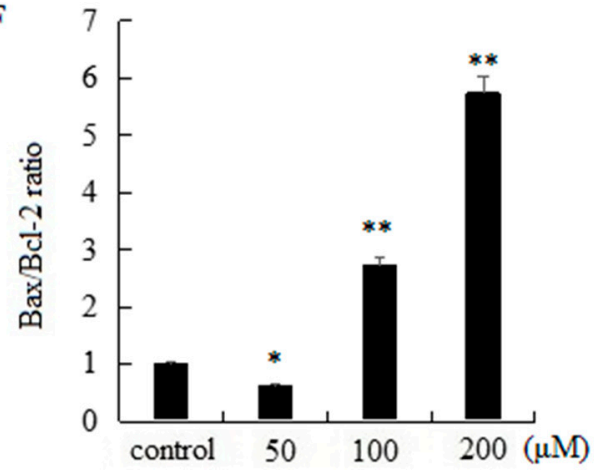

Figure 5. Expression levels of Bax and Bcl-2 and Bax/Bcl-2 ratio in HGC-27 and AGS cells. (A) HGC-27 cells; (B) relative expression levels of Bax and Bcl-2 in HGC-27 cells; (C) Bax/Bcl-2 ratio in HGC-27 cells; (D) AGS cells; (E) relative expression levels of Bax and Bcl-2 in AGS cells; (F) Bax/Bcl-2 ratio in AGS cells. ${ }^{*} p<0.05$ and ${ }^{* *} p<0.01$ vs. control group.

\subsection{AT-II Inhibits the Phosphorylation of ERK and Akt in HGC-27 and AGS Cells}

ERK and Akt played an important role in cell proliferation, apoptosis, migration and staying cell morphology. ERK and Akt were activated through phosphorylating tyr202/204 and ser473 residues, respectively, and exerted their functions [20,21]. We evaluated the expression levels of total ERK and p-ERK by Western blot after treated with AT-II for $48 \mathrm{~h}$. The activation level of ERK was downregulated significantly by AT-II in a dose-dependent manner. Furthermore, we also analyzed the activation pattern of another signaling protein Akt. As shown in Figure 6, a downregulation in the activation of p-Akt was observed after AT-II treatment. 
A

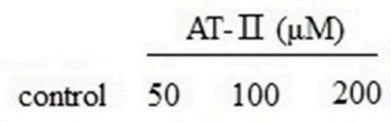

p-ERK

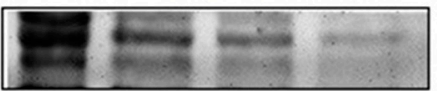

ERK

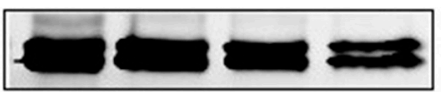

p-Akt

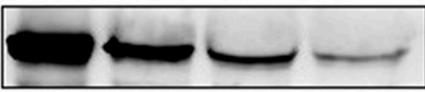

Akt

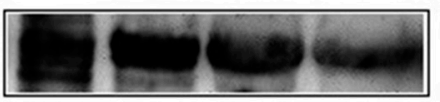

$\beta$-actin

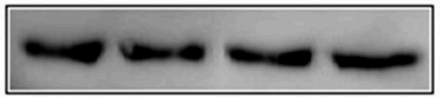

C

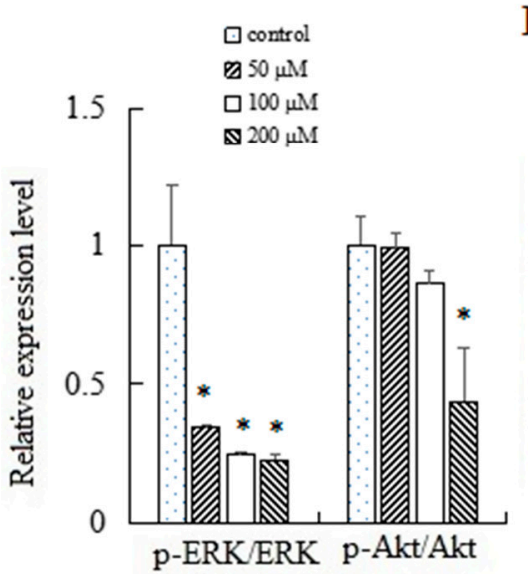

B

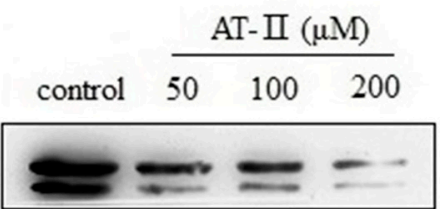

ERK

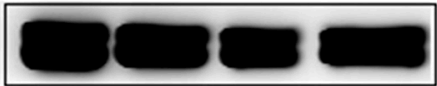

p-Akt

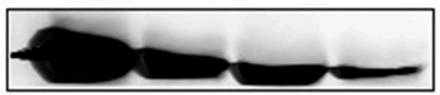

Akt

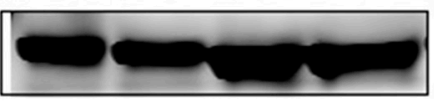

$\beta$-actin

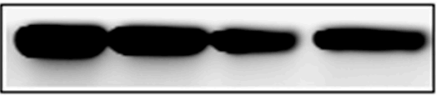

D

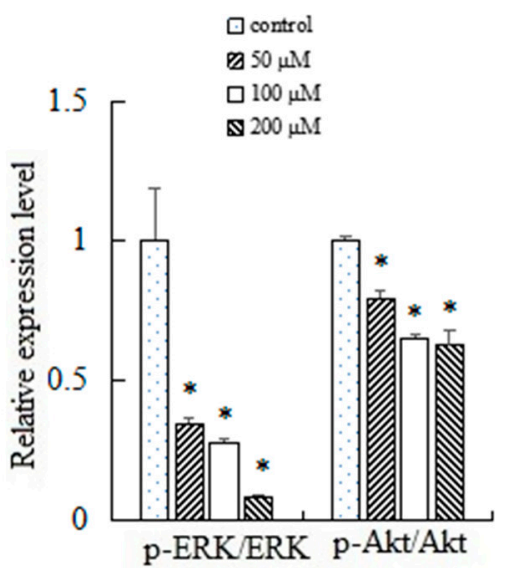

Figure 6. Expression levels of ERK, p-ERK, Akt and p-Akt in HGC-27 and AGS cells. (A) HGC-27 cells; (B) AGS cells; (C) relative expression levels of p-ERK/ERK and p-Akt/Akt in HGC-27 cells; (D) relative expression levels of p-ERK/ERK and p-Akt/Akt in AGS cells. ${ }^{*} p<0.05$ vs. control group.

\section{Discussion}

Cell apoptosis, which was involved in physiological growth regulation and tissue homeostasis is a complex and multistage process containing many genes [22,23]. So far, inducing apoptosis is considered as one of the best strategies in cancer therapy. In this study, the effects of AT-II on cell apoptosis were detected by Annexin V-FITC and PI staining. Annexin V-FITC could especially bind to phosphatidylserine, which can translocate from the inner side of the cell membrane to the outer side of the cell membrane during early cell apoptosis. Thus, Annexin V-FITC was used to evaluate the early apoptotic cells and PI was used to evaluate late apoptotic cells and necrotic cells. Flow cytometry results showed that the percentage of apoptotic cells were significantly increased and positively related to the concentrations of AT-II. However, the effects of AT-II on apoptosis in HGC-27 and AGS cells are different. HGC-27 cells are more sensitive than AGS cells to AT-II. AT-II could induce apoptosis in HGC-27 cells when exposed to $100 \mu \mathrm{M}$, while AGS cells were induced apoptosis only when the concentration of AT-II reached to $200 \mu \mathrm{M}$. The differences between HGC-27 cells and AGS cells may be because of differentiated stage. HGC-27 cells are undifferentiated gastric carcinoma cell, while AGS cells are derived from untreated tumor fragments belong to poor differentiated gastric carcinoma cells. At the same time, mitochondria-mediated apoptosis pathway is well understood and Bcl-2 family proteins play an important role in controlling mitochondrial pathway. Bax is pro-apoptotic protein, which could interact with voltage-dependent ion channel of mitochondria membrane and induce the release of cytochrome $\mathrm{C}$. In contrast, $\mathrm{Bcl}-2$ is anti-apoptotic protein, 
which prevents the release of cytochrome $C$ from mitochondria to cytoplasm [24-26]. Consistent with the above results, Western blot analysis revealed AT-II treatment resulted in the upregulation of Bax, the downregulation of Bcl-2 and an increase of the Bax/Bcl-2 ratio in both two cell lines. These data suggested that AT-II induced mitochondrial dependent apoptosis pathway though regulating apoptosis related proteins and the ratio of $\mathrm{Bax} / \mathrm{Bcl}-2$.

Cancer metastasis is the major cause of morbidity and mortality in millions of patients with cancer, and the migration of cancer cells is one of the important steps during the invasion. If an agent can inhibit proliferation and migration of tumor cells, it might be hopeful to suppress cancer progression and metastasis and reduce death rates [27]. In our research, we found that AT-II was able to inhibit cell proliferation and motility in a concentration and time-dependent manner in HGC-27 and AGS cells, indicating that AT-II may inhibit metastasis of invasive gastric cells.

Ras/ERK and PI3K/Akt signaling pathways are vital for cell proliferation, differentiation, survival, motility, metabolism, tumor development and drug resistant. It is reported that both two signaling pathways are constantly activated in many cancers [28,29]. ERK is phosphorylated and activated by mitogen though the Ras/Raf/MEK signaling pathway. Then, p-ERK stimulates the transcription of some related proteins and is involved in cell proliferation, apoptosis and migration [30,31]. Akt, as an important downstream effecter of PI3K, is activated by phosphorylating. Activated Akt phosphorylats several downstream targets of the survival and apoptotic pathways and exerts its functions [32,33]. Our results demonstrated that AT-II treatment resulted in decreasing the levels of p-ERK and p-Akt, which was accompanied by the downregulation of Bcl-2. The data suggested that AT-II may, through modulating ERK and Akt signaling pathways, inhibit cell proliferation, motility and induce apoptosis.

In summary, our results indicate that AT-II exerts anti-cancer effects by inhibiting proliferation, motility and inducing apoptosis and may be due to inactivating Ras/ERK and PI3K/Akt signaling pathways, which might shed light on therapy of gastric carcinoma.

\section{Materials and Methods}

\subsection{Reagents}

AT-II (purity $\geq 98 \%$ ) was purchased from Must Bio-technology Co., Ltd. (Chengdu, China). Dimethyl sulfoxide (DMSO) was purchased from Sigma (St. Louis, MO, USA). CCK-8 Kit and human Bcl-2, Bax, Akt, p-Akt, ERK, p-ERK and $\beta$-actin polyclonal antibodies were purchased from Beyotime (Shanghai, China). Annexin V-FITC Apoptosis Detection Kit was purchased from KeyGEN BioTECH (Nanjing, China).

\subsection{Cell Lines and Cell Culture}

Human gastric cancer cell lines HGC-27 and AGS were purchased from Cell Bank of Type Culture Collection of Chinese Academy of Sciences (Shanghai, China). Human normal gastric mucosal epithelium cell lines GES-1 was supplied by The First Hospital of China Medical University (Shenyang, China). All cells were cultured in RPMI-1640 medium supplemented with $10 \%$ fetal bovine serum (FBS), $100 \mathrm{U} / \mathrm{mL}$ penicillin and $100 \mu \mathrm{g} / \mathrm{mL}$ streptomycin at $37^{\circ} \mathrm{C}$.

\subsection{Cell Growth Assay}

CCK-8 assay was used to determine relative cell viability after AT-II treatment for $24 \mathrm{~h}$, $48 \mathrm{~h}$ and $72 \mathrm{~h}$, respectively. HGC-27, AGS and GES-1 cells were seeded in 96-well plates at a density of $3 \times 10^{3}$ cells/well and treated with AT-II diluted by complete medium at serial concentrations $(0 / 50 / 100 / 200 / 400 \mu \mathrm{M})$ on the next day. CCK-8 solution of $10 \mu \mathrm{L}$ was added to each well and cells were incubated for another $1 \mathrm{~h}$ at $37^{\circ} \mathrm{C}$. Then, the optical density was measured at $450 \mathrm{~nm}\left(\mathrm{~A}_{450}\right)$. 


\subsection{Cell Morphological Assessment}

HGC-27 and AGS cells were seeded in 24-well plates and treated with different concentrations of AT-II $(0 / 50 / 100 / 200 \mu \mathrm{M})$ for $48 \mathrm{~h}$. Then, the morphological changes of cells were observed under an inverted microscope (Olympus, Tokyo, Japan).

\subsection{Apoptosis Assay}

Cell apoptosis rates were detected by flow cytometry tests. HGC-27 and AGS cells were seeded in 6-well plates $\left(2 \times 10^{5}\right.$ cells / well) and, on the following day, were exposed to AT-II with 0, 50, 100 and $200 \mu \mathrm{M}$ for $48 \mathrm{~h}$. Cells were collected, rinsed with PBS, re-suspended in binding buffer and incubated with Annexin V-FITC and PI for 5-15 min at room temperature in the dark and then samples were analyzed within $1 \mathrm{~h}$ by FACS Calibur (BD Biosciences, Shanghai, China).

\subsection{Wound Healing Assay}

The motility and spreading capabilities of the cells were calculated by wound healing assay. HGC-27 and AGS cells were seeded in 24-well plates $\left(5 \times 10^{4}\right.$ cells/well) and cultured to near $(>90 \%)$ confluence. A sterile $200 \mu \mathrm{L}$ pipette tip was used to scratch a separate wound through cell monolayers. Then, the medium was removed and replaced with fresh medium containing 0,50, 100 and $200 \mu \mathrm{M}$ of AT-II. Pictures were taken to ensure that the line just appears in each picture at $0 \mathrm{~h}, 24 \mathrm{~h}$ and $48 \mathrm{~h}$, respectively.

\subsection{Western Blot Analysis}

HGC-27 and AGS cells were seeded in 6-well plates $\left(2 \times 10^{5}\right.$ cells/well $)$ and were treated with different doses of AT-II on the following day. After $48 \mathrm{~h}$, total protein was extracted by Radio Immunoprecipitation Assay (RIPA) buffer ( $1 \mathrm{mM} \mathrm{MgCl}_{2}, 10 \mathrm{mM}$ Tris-HCl, $\mathrm{pH} 7.4,1 \%$ Triton X-100, $0.1 \%$ SDS and $1 \%$ NP-40). Protein expression level was analyzed by Western blot. Proteins ( $25 \mu \mathrm{g} /$ well $)$ were separated on $10 \%$ SDS-PAGE gels and transferred to PVDF membranes. After that, the membranes were blocked in $1 \%$ bovine serum albumin (BSA) for $1 \mathrm{~h}$ at room temperature and incubated overnight with primary antibodies of target proteins at $4{ }^{\circ} \mathrm{C}$. With $\beta$-actin as a loading control, the expression levels of Bax, Bcl-2, Akt, p-Akt, ERK and p-ERK were evaluated out and quantified by Labworks 4.0 software.

\subsection{Statistical Analysis}

All experiments were performed three times and the results were represented as mean \pm standard deviation (SD). Statistical analysis used the Duncan test and one-way analysis of variance (ANOVA), with $p<0.05$ considered to be significant and $p<0.01$ considered to be significant remarkably.

Acknowledgments: The authors thank the Life Science Institute of Jinzhou Medical University in China for providing the necessary equipment of this work.

Author Contributions: Shuang Tian designed the experiments; Shuang Tian and Hongdan Yu performed the experiments; Shuang Tian analyzed the data and wrote the paper.

Conflicts of Interest: The authors declare no conflict of interest.

\section{References}

1. Ferlay, J.; Soerjomataram, I.; Dikshit, R.; Eser, S.; Mather, C.; Rebelo, M.; Parkin, D.M.; Forman, D.; Bray, F. Cancer incidence and mortality worldwide: Sources, methods and major patterns in GLOBOCAN 2012. Int. J. Cancer 2015, 136, E359-E386. [CrossRef] [PubMed]

2. Catalano, V.; Labianca, R.; Beretta, G.D.; Gatta, G.; De, B.F.; Van, C.E. Gastric cancer. Oncol. Hematol. 2009, 71, 127-164. [CrossRef] [PubMed] 
3. Ajani, J.A.; Bentrem, D.J.; Besh, S.; D’Amico, T.A.; Das, P.; Denlinger, C.; Fakih, M.G.; Fuchs, C.S.; Gerdes, H.; Glasgow, R.E.; et al. Gastric cancer, version 2.2013: Featured updates to the NCCN Guidelines. J. Natl. Compr. Canc. Netw. 2013, 11, 531-546. [CrossRef] [PubMed]

4. Ma, L.; Mao, R.R.; Shen, K.; Zheng, Y.H.; Li, Y.Q.; Liu, J.W.; Ni, L. Atractylenolide I-mediated Notch pathway inhibition attenuates gastric cancer stem traits. BBRC 2014, 450, 353-359. [CrossRef] [PubMed]

5. Wu, J.; Tan, Z.J.; Chen, J.; Dong, C. Cyclovirobuxine D Inhibits cell proliferation and induces mitochondria-mediated apoptosis in human gastric cancer cells. Molecules 2015, 20, 20659-20668. [CrossRef] [PubMed]

6. Villarreal-García, D.; Nair, V.; Cisneros-Zevallos, L.; Jacobo-Velázquez, D.A. NaiPlants as biofactories: postharvest stress-induced accumulation of phenolic compounds and glucosinolates in broccoli subjected to wounding stress and exogenous phytohormones. Front. Plant. Sci. 2016, 7, 45-55. [CrossRef] [PubMed]

7. Leyva-López, N.; Nair, V.; Bang, W.Y.; Cisneros-Zevallos, L.; Heredia, J.B. Protective role of terpenes and polyphenols from three species of Oregano (Lippiagraveolens, Lippiapalmeri and Hedeoma patens) on the suppression of lipopolysaccharide-induced inflammation in RAW 264.7 macrophage cells. J. Ethnopharmacol. 2016, 187, 302-312. [CrossRef] [PubMed]

8. Ambriz-Pérez, D.L.; Bang, W.Y.; Nair, V.; Angulo-Escalante, M.A.; Cisneros-Zevallos, L.; Heredia, J.B. Protective role of flavonoids and lipophilic compounds from jatrophaplatyphylla on the suppression of Lipopolysaccharide (LPS)-induced inflammation in macrophage Cells. J. Agric. Food Chem. 2016, 64, 1899-1909. [CrossRef] [PubMed]

9. Zheng, L.; Shao, Z.-D.; Wang, Z.-C.; Fu, C.-X. Isolation and characterization of polymorphic microsatellite markers from the Chinese medicinal herb Atractylodes macrocephala (Asteraceae). Int. J. Mol. Sci. 2012, 13, 16046-16052. [CrossRef] [PubMed]

10. Liu, H.Y.; Zhu, Y.J.; Zhang, T.; Zhao, Z.G.; Zhao, Y.; Cheng, P.; Li, H.; Gao, H.; Su, X.M. Anti-tumor effects of atractylenolide I isolated from Atractylodes macrocephala in human lung carcinoma cell lines. Molecules 2013, 18, 13357-13368. [CrossRef] [PubMed]

11. Chen, L.G.; Jan, Y.S.; Tsai, P.W.; Norimoto, H.; Michihara, S.; Murayama, C.; Wang, C.C. Anti-inflammatory and antinociceptive constituents of Atractylodes japonica Koidzumi. J. Agric. Food Chem. 2016, 64, 2254-2262. [CrossRef] [PubMed]

12. Hoang, L.S.; Tran, M.H.; Lee, J.S.; Ngo, Q.M.T.; Woo, M.H.; Min, B.S. Inflammatory inhibitory activity of sesquiterpenoids from Atractylodes macrocephala rhizomes. Chem. Pharm. Bull. (Tokyo) 2016, 64, 507-511. [CrossRef] [PubMed]

13. Li, X.; Liu, F.; Li, Z.; Ye, N.; Huang, C.; Yuan, X. Atractylodes macrocephala polysaccharides induces mitochondrial-mediated apoptosis in glioma C6 cells. Int. J. Biol. Macromol. 2014, 66, 108-112. [CrossRef] [PubMed]

14. Singhuber, J.; Baburin, I.; Kählig, H.; Urban, E.; Kopp, B.; Hering, S. GABA(A) receptor modulators from Chinese herbal medicines traditionally applied against insomnia and anxiety. Phytomedicine 2012, 19, 334-340. [CrossRef] [PubMed]

15. Zhang, N.; Liu, C.; Sun, T.M.; Ran, X.K.; Kang, T.G.; Dou, D.Q. Two new compounds from Atractylodes macrocephala with neuroprotective activity. J. Asian Nat. Prod. Res. 2017, 19, 35-41. [CrossRef] [PubMed]

16. Chen, Y.Z.; Yang, W.L.; Guo, L.Y.; Wu, X.L.; Zhang, T.T.; Liu, J.L.; Zhang, J.F. Atractylodes lactone compounds inhibit platelet activation. Platelets 2016, 28, 194-202. [CrossRef] [PubMed]

17. Fu, X.Q.; Chou, G.X.; Kwan, H.Y.; Tse, A.K.; Zhao, L.H.; Yuen, T.K.; Cao, H.H.; Yu, H.; Chao, X.J.; Su, T.; et al. Inhibition of STAT3 signaling contributes to the antimelanoma action of atractylenolide II. Exp. Dermatol. 2014, 23, 855-857. [CrossRef] [PubMed]

18. Ye, Y.; Wang, H.; Chu, J.H.; Chou, G.X.; Chen, S.B.; Mo, H.B.; Fong, W.F.; Yu, Z.L. Atractylenolide II inducesG1 cell-cycle arrest and apoptosis in B16 melanomacells. J. Ethnopharmacol. 2011, 136, 279-282. [CrossRef] [PubMed]

19. Farzaneh, S.H.; Soudeh, K.F.; Mohammad, R.H.; Alireza, K.; Mohammad, R.M.; Hadis, A.; Reza, B.; Nesa, J.; Mehdi, M. Persian shallot, Allium hirtifolium Boiss, induced apoptosis in human hepatocellular carcinoma cells. Cytotechnology 2017, 69, 551-563. 
20. Fei, H.R.; Chen, G.; Wang, J.M.; Wang, F.Z. Perifosine induces cell cycle arrest and apoptosis in human hepatocellular carcinoma cell lines by blockade of Akt phosphorylation. Cytotechnology 2010, 62, 449-460. [CrossRef] [PubMed]

21. Li, R.; Wu, Y.; Jiang, D. NT-3 attenuates the growth of human neuron cells through the ERK pathway. Cytotechnology 2016, 68, 659-664. [CrossRef] [PubMed]

22. Tang, Y.P.; Yu, F.M.; Zhang, G.M.; Yang, Z.S.; Huang, F.F.; Ding, G.F. A purified serine protease from Nereis virens and its impaction of apoptosis on human lung cancer cells. Molecules 2017, 22, 1123. [CrossRef] [PubMed]

23. Wang, Z.; Wu, X.; Liang, Y.N.; Wang, L.; Song, Z.X.; Liu, J.L.; Tang, Z.S. Cordycepin induces apoptosis and inhibits proliferation of human lung cancer cell line H1975 via Inhibiting the Phosphorylation of EGFR. Molecules 2016, 21, 1267. [CrossRef] [PubMed]

24. Long, F.Y.; Wang, T.; Jia, P.; Wang, H.F.; Qing, Y.; Xiong, T.T.; He, M.J.; Wang, X.L. Anti-tumor effects of Atractylenolide-I on human ovarian cancer cells. Med. Sci. Monit. 2017, 23, 571-579. [CrossRef] [PubMed]

25. Chen, D.; Sun, S.P.; Cai, D.W.; Kong, G.Q. Induction of mitochondrial-dependent apoptosis in T24 cells by a selenium (Se)-containing polysaccharide from Ginkgo Biloba L. leaves. Int. J. Biol. Macromol. 2017, 101, 126-130. [CrossRef] [PubMed]

26. Li, Y.; Li, D.J.; Chen, J.; Wang, S.G. A polysaccharide from Pinellia ternata inhibits cell proliferation and metastasis in human cholangiocarcinoma cells by targeting of Cdc42 and $67 \mathrm{kDa}$ Laminin Receptor (LR). Int. J. Biol. Macromol. 2016, 93, 520-525. [CrossRef] [PubMed]

27. Liu, Y.; Bi, T.T.; Shen, G.H.; Li, Z.M.; Wu, G.L.; Wang, Z.; Qian, L.Q.; Gao, Q.G. Lupeol induces apoptosis and inhibits invasion in gallbladder carcinoma GBC-SD cells by suppression of EGFR/MMP-9 signaling pathway. Cytotechnology 2016, 68, 123-133. [CrossRef] [PubMed]

28. Ye, Y.; Chou, G.X.; Wang, H.; Chu, J.H.; Fong, W.F.; Yu, Z.L. Effects of sesquiterpenes isolated from largehead atractylodes rhizome on growth, migration, and differentiation of B16 melanoma cells. Integr. Cancer Ther. 2011, 10, 92-100.

29. Yu, R.; Yu, B.X.; Chen, J.F.; Lv, X.Y.; Yan, Z.J.; Cheng, Y.; Ma, Q. Anti-tumor effects of Atractylenolide I on bladder cancer cells. J. Exp. Clin. Cancer Res. 2016, 35, 40-49. [CrossRef] [PubMed]

30. Bi, C.; Jiang, Y.N.; Fu, T.T.; Hao, Y.; Zhu, X.F.; Lu, Y. Naringin inhibits lipopolysaccharide-induced damage in human umbilical vein endothelial cells via attenuation of inflammation, apoptosis and MAPK pathways. Cytotechnology 2016, 68, 1473-1487. [CrossRef] [PubMed]

31. Zhang, R.; Wang, G.; Zhang, P.F.; Zhang, J.; Huang, Y.X.; Lu, Y.M.; Da, W.; Sun, Q.; Zhu, J.S. Sanguinarine inhibits growth and invasion of gastric cancer cells via regulation of the DUSP4/ERK pathway. J. Cell. Mol. Med. 2017, 21, 1117-1127. [CrossRef] [PubMed]

32. Yao, J.; Qian, C.J. Sporamin induce apoptosis in human tongue carcinoma cells by down-regulating Akt/GSK-3 signaling. Fundam. Clin. Pharmacol. 2010, 25, 229-236. [CrossRef] [PubMed]

33. Sun, B.Z.; Chen, L.; Wei, X.B.; Xiang, Y.X.; Liu, X.Q.; Zhang, X.M. The Akt/GSK-3 $\beta$ pathway mediates flurbiprofen-induced neuroprotection against focal cerebral ischemia/reperfusion injury in rats. Biochem. Biophys. Res. Commun. 2011, 409, 808-813. [CrossRef] [PubMed]

Sample Availability: Not Available.

(C) 2017 by the authors. Licensee MDPI, Basel, Switzerland. This article is an open access article distributed under the terms and conditions of the Creative Commons Attribution (CC BY) license (http://creativecommons.org/licenses/by/4.0/). 